\title{
Deficiency of Src Family Kinases Fgr and Hck Results in Activation of Erythrocyte $\mathrm{K} / \mathrm{Cl}$ Cotransport
}

\author{
Lucia De Franceschi, ${ }^{\star}$ Laura Fumagalli, ${ }^{\ddagger}$ Oliviero Olivieri, ${ }^{\star}$ Roberto Corrocher, ${ }^{\star}$ Clifford A. Lowell, ${ }^{\S}$ Giorgio Berton ${ }^{\ddagger}$ \\ *Institute of Internal Medicine and ${ }^{\ddagger}$ Institute of General Pathology, University of Verona, 37134 Verona, Italy; and ${ }^{\S}$ Department of \\ Laboratory Medicine, University of California, San Francisco, California 94143
}

\begin{abstract}
Src-family kinases play a central role in regulation of hematopoietic cell functions. We found that mouse erythrocytes express the Src-family kinases Fgr and Hck, as well as Lyn. To directly test whether Fgr and Hck play any role in erythrocyte function, we analyzed red cells isolated from $\mathrm{fgr}^{-1-}, \boldsymbol{h c k}^{-1-}$, and $\mathrm{fgr}^{-1-} \boldsymbol{h c k}^{-1-}$ knock-out mice. Mean corpuscular hemoglobin concentration and median density are increased, while $\mathrm{K}$ content is decreased, in $\mathrm{fgr}^{-1-} \boldsymbol{h c k}^{-l-}$ double-mutant erythrocytes compared with wild-type, $\mathrm{fgr}^{-l-}$, or $h \boldsymbol{c k}^{-l-}$ erythrocytes. $\mathrm{Na} / \mathrm{K}$ pump and $\mathrm{Na} / \mathrm{K} / \mathrm{Cl}$ cotransport were not altered, but $\mathrm{K} / \mathrm{Cl}$ cotransport activity was significantly and substantially higher (approximately threefold) in $\mathrm{fgr}^{-1-} \mathrm{hck}^{-1-}$ double-mutant erythrocytes. This enhanced $\mathrm{K} / \mathrm{Cl}$ cotransport activity did not depend on cell age. In fact, in response to bleeding, $\mathrm{K} / \mathrm{Cl}$ cotransport activity increased in parallel with reticulocytosis in wild-type erythrocytes, while abnormal $\mathrm{K} / \mathrm{Cl}$ cotransport did not change as a consequence of reticulocytosis in $\mathrm{fgr}^{-/-} \mathrm{hck}^{-/-}$ double-mutant erythrocytes. Okadaic acid, an inhibitor of a phosphatase that has been implicated in activation of the $\mathrm{K} / \mathrm{Cl}$ cotransporter, inhibited $\mathrm{K} / \mathrm{Cl}$ cotransport in wild-type and $f \mathrm{gr}^{-1-} \mathrm{hck}^{-1-}$ double-mutant erythrocytes to a comparable extent. In contrast, staurosporine, an inhibitor of a kinase that has been suggested to negatively regulate this same phosphatase enhanced $\mathrm{K} / \mathrm{Cl}$ cotransport in wild-type but not in $\mathrm{fgr}^{-1-} \mathrm{hck}^{-1-}$ double-mutant erythrocytes. On the basis of these findings, we propose that Fgr and Hck are the kinases involved in the negative regulation of the $\mathrm{K} / \mathrm{Cl}$ cotransporter-activating phosphatase. Abnormality of erythrocyte $\mathrm{K} / \mathrm{Cl}$ cotransport in $\mathrm{fgr}^{-l-} \boldsymbol{h} \mathrm{ck}^{-1-}$ double-mutant animals represents the first demonstration that Src-family kinases may be involved in regulation of membrane transport. (J. Clin. Invest. 1997. 99:220-227.) Key words: tyrosine kinase - membrane transport • erythrocyte • gene knockout • phosphorylation
\end{abstract}

\section{Introduction}

The volume and hemoglobin concentration of red cells are determined by erythrocyte ion and water content, which are reg-

Address correspondence to Giorgio Berton, Istituto di Patologia Generale, Strada Le Grazie, 37134 Verona, Italy. Phone: +39-458098126; FAX: +39-45-8098127; E-mail: gberto@borgoroma.univr.it

Received for publication 12 August 1996 and accepted in revised form 5 November 1996.

J. Clin. Invest.

(C) The American Society for Clinical Investigation, Inc. 0021-9738/97/02/220/08 \$2.00

Volume 99, Number 2, January 1997, 220-227 ulated by several volume-sensitive transporters (1-3). The $\mathrm{K} / \mathrm{Cl}$ cotransport system represents a fast gradient-driven transporter that has been described in human, sheep, dog, rabbit, avian, and mouse erythrocytes. The $\mathrm{K} / \mathrm{Cl}$ cotransporter also plays a significant role in red cell abnormalities in patients homozygous for hemoglobin $\mathrm{C}$, hemoglobin $\mathrm{S}$, and $\beta$ thalassemia (1-11). In human erythrocytes, the $\mathrm{K} / \mathrm{Cl}$ cotransport is present in the least dense, reticulocyte-rich fraction of normal red cells; as red cells age, $\mathrm{K} / \mathrm{Cl}$ cotransport activity declines $(5,6)$. Erythrocyte swelling caused by hypotonicity or cytoplasmic acidification, also activates the $\mathrm{K} / \mathrm{Cl}$ cotransporter, inducing $\mathrm{K}$ loss and cell shrinkage (3-9). In addition, this cotransport system has been shown to be activated by oxidative damage of the red cell membrane $(7,12)$.

Recently, models describing the mechanisms of regulation and kinetic properties of the $\mathrm{K} / \mathrm{Cl}$ cotransporter have been proposed (13-18). These models highlighted the importance of a dephosphorylation/phosphorylation cycle in regulating $\mathrm{K} / \mathrm{Cl}$ cotransport activity as demonstrated by studies with inhibitors of serine/threonine protein phosphatases or protein kinases. Treatment of human, mouse, rabbit, and low K sheep red cells with okadaic acid $(\mathrm{OA})^{1}$, a phosphatase inhibitor, inhibits $\mathrm{K} / \mathrm{Cl}$ cotransport $(15,16,19)$. In low $\mathrm{K}$ sheep and mouse red cells, the cotransport is activated by staurosporine, a protein kinase inhibitor $(10,11,17)$. These findings suggest that phosphorylation of the $\mathrm{K} / \mathrm{Cl}$ cotransporter, or of a regulatory molecule, decreases activity, while dephosphorylation increases activity (see reference 20). However, protein kinases implicated in regulation of $\mathrm{K} / \mathrm{Cl}$ cotransport have not yet been identified.

Several studies have addressed the role of specific protein kinases in the regulation of erythrocyte ion transport. Interestingly, it was shown that $\mathrm{p} 72^{\mathrm{syk}}$ and $\mathrm{p} 53 / 56^{\mathrm{lyn}}$, members of two distinct families of tyrosine kinases, the Syk/ZAP-70 and the Src, respectively, are expressed in human erythrocytes (21). Both Syk/ZAP-70 and Src-family tyrosine kinases are widely expressed in hematopoietic cells (reviewed in references 2224). The Src-family of tyrosine kinases contains at least nine members (Src, Yes, Fyn, Lyn, Lck, Hck, Fgr, Blk, Yrk), some of which are expressed in a variety of cell types, whereas others are expressed primarily by hematopoietic cells. The expression of Src-family kinases in hematopoietic cells varies considerably and each lineage of cells contains more than one family member. For example, p53/56 $6^{\mathrm{lyn}}$ is highly expressed by B, but not $\mathrm{T}$, lymphocytes and by myelomonocytic cells (22). Myelomonocytic cells also express the p58 c-fgr and p59/61 ${ }^{\text {hck }}$ kinases $(22,25,26)$. In addition, these two kinases are also ex-

1. Abbreviations used in this paper: $\mathrm{D}_{50}$, median density; $\mathrm{Hb}$, hemoglobin; Hct, hematocrit; MCHC, mean corpuscolar hemoglobin concentration; NEM, $N$-ethylmaleimide; OA, okadaic acid. 
pressed by B cell lines $(25,26)$, and recently it has been shown that mature B lymphocytes express Fgr $(27,28)$.

The evidence that erythrocytes express $\mathrm{p} 53 / 56^{\mathrm{lyn}}$ prompted us to investigate whether $\mathrm{p} 58^{\mathrm{c}-\mathrm{fgr}}$ and $\mathrm{p} 59 / 61^{\mathrm{hck}}$ are also expressed in these cells. Indeed, we found that mouse erythrocytes express $\mathrm{p} 58^{\mathrm{c}-\mathrm{fgr}}$ and $\mathrm{p} 59 / 61^{\text {hck }}$. To investigate the possible role of these two kinases in regulating erythrocyte functions, we exploited the availability of mice in which the $f g r$ and $h c k$ genes were inactivated (29; see reference 24 for a review on knock outs of Src-family kinases). Early studies showed that double-mutant $\mathrm{fgr}^{-1-} h \mathrm{ck}^{-1-}$ mice have an impairment of natural immunity, being more susceptible to Listeria monocytogenes infection (29). More recent studies established that integrin signaling is defective in $\mathrm{fgr}^{-/-} \mathrm{hck}^{-/-}$neutrophils (30).

In this report, we show that in erythrocytes from $\mathrm{fgr}^{-/-}$ $h c k^{-/-}$double-mutant mice the activity of the $\mathrm{K} / \mathrm{Cl}$ cotransport is increased, thus causing red cell dehydration and shrinkage. These results strongly argue that the $\mathrm{p} 58^{\mathrm{c}-\mathrm{fgr}}$ and $\mathrm{p} 59 / 61^{\mathrm{hck}} \mathrm{ki}-$ nases are involved in regulation of $\mathrm{K} / \mathrm{Cl}$ cotransport in erythrocytes. Together with the evidence that $\mathrm{p} 72^{\text {syk }}$ phosphorylates the anion transporter, band 3 (21), our findings point to an important role for tyrosine kinases in regulation of erythrocyte membrane transport.

\section{Methods}

Drugs and chemicals. $\mathrm{NaCl}, \mathrm{KCl}, \mathrm{NaNO}_{3}, \mathrm{MgCl}_{2}, \mathrm{OA}$, staurosporine, ouabain, bumetanide, nystatin, $\mathrm{Mg}\left(\mathrm{NO}_{3}\right)_{2}$, DMSO, $n$-butyl phthalate, TRIS, and MOPS were purchased from Sigma Chemical Co. (St. Louis, MO). Sulfamic acid was purchased from Aldrich Chemical Co. (Milwaukee, WI). Choline chloride was purchased from Calbiochem-Novabiochem Corp. (San Diego, CA). Bovine serum albumin fraction $\mathrm{V}$ was purchased from Boehringer Mannheim (Mannheim, Germany). All solutions were prepared using doubledistilled water.

Animals and design of the study. Male (28-30 g) and female (25$28 \mathrm{~g}$ ) wild-type, and $\mathrm{grr}^{-1-}, h c k^{-1-}$, or $f g r^{-/-} h c k^{-/-}$double knock-out mice, varying in age between 8 and $16 \mathrm{wk}$, were used in this study (see reference 29). A group of six animals for each strain of mice was used for studying the effect of cell age on $\mathrm{K} / \mathrm{Cl}$ cotransport activity. To this purpose, $450 \mu$ l blood ( $30 \%$ of total blood volume) was drawn every $4 \mathrm{~d}$, three times, and replaced with equal amounts of sterile isotonic saline injected intraperitoneally. $\mathrm{K} / \mathrm{Cl}$ cotransport, cell cation content, and density distribution curves were determined at baseline (day 0 ) and after 14, 28, and $35 \mathrm{~d}$ from the start of the bleeding protocol. Blood was collected into heparinized microhematocrit tubes by retroorbital venipuncture from ether-anesthetized mice.

In vitro kinase assays. For preparation of erythocytes, whole blood was passed through cotton to remove leukocytes and red cells were washed four times in isotonic saline. $0.4 \mathrm{ml}$ washed, packed erythrocytes were diluted with $1 \mathrm{ml}$ isotonic saline, and then lysed by addition of $0.4 \mathrm{ml}$ of $4 \times$ RIPA buffer (100 mM Tris, $\mathrm{pH} 7.5,600 \mathrm{mM}$ $\mathrm{NaCl}, 4 \%$ Triton $\mathrm{X}-100,4 \%$ Na-deoxycholate, $0.4 \%$ SDS, $4 \mathrm{mM}$ DTT, $20 \mu \mathrm{g} / \mathrm{ml}$ pepstatin, $20 \mu \mathrm{g} / \mathrm{ml}$ leupeptin, $4 \mathrm{mM}$ diisopropyl fluorophosphate, $400 \mu \mathrm{M}$ Na-orthovanadate, $40 \mu \mathrm{M}$ phenylarsine oxide). After $10 \mathrm{~min}$ of incubation in ice, lysates were centrifuged at $12,000 \mathrm{~g}$ for $10 \mathrm{~min}$ at $4^{\circ} \mathrm{C}$ and supernatants were transferred to microfuge tubes. Lysates were precleared by incubation for $1 \mathrm{~h}$ at $4^{\circ} \mathrm{C}$, in a rotating wheel, with $30 \mu \mathrm{l}$ of protein A immobilized to Trysacryl (Pierce Chemical Co., Rockford, IL). After preclearing, lysates were incubated with $20 \mu \mathrm{l}$ protein A-Trysacryl preadsorbed with rabbit antiFgr, anti-Hck, and anti-Lyn Abs. The Abs used were described in a previous study (29). Incubations were for $3 \mathrm{~h}$ at $4^{\circ} \mathrm{C}$ in a rotating wheel. At the end of incubation, immunocomplexes were collected by centrifugation in a microfuge, washed twice with RIPA buffer $(25$ $\mathrm{mM}$ Tris, pH 7.5, $150 \mathrm{mM} \mathrm{NaCl}, 1 \%$ Triton X-100, 1\% Na-deoxycho- late, $0.1 \%$ SDS), once with TBS ( $170 \mathrm{mM} \mathrm{NaCl}, 50 \mathrm{mM}$ Tris, $\mathrm{pH} 7.5)$ and once with kinase buffer (20 mM Hepes, pH 7.4, $10 \mathrm{mM} \mathrm{MnCl}_{2}$, $1 \mathrm{mM}$ DTT). Immunocomplexes were resuspended in $20 \mu \mathrm{l}$ kinase buffer containing $2 \mu \mathrm{Ci}{ }^{32} \mathrm{P}-\gamma$-ATP (Amersham International, Little Chalfont, UK; specific activity 5,000 Ci/mmol) and incubated at room temperature for $10 \mathrm{~min}$ (31). The reaction was stopped with heated $\left(95^{\circ} \mathrm{C}\right)$ SDS sample buffer, and samples electrophoresed on $10 \%$ SDS/PAGE gels, dried and processed for autoradiography as described in reference 31 .

Determination of hematological parameters and red cell cation content. Hemoglobin $(\mathrm{Hb})$ concentration was determined by spectroscopic measurement of the cyanmet derivative. Hematocrit (Hct) was determined by centrifugation in a micro-Hct centrifuge. Mean corpuscular hemoglobin concentration (MCHC) was calculated from $\mathrm{Hb}$ and Hct values. Reticulocytes were counted on EPICS Profile II (Coulter Immunology, Hialeah, FL) after thiazole orange staining $(10,11,32,33)$. Density distribution curves were obtained according to Danon and Marikovsky (34), using phthalate esters microhematocrit tubes, after washing the cells three times with PBS (330 mosM) at $25^{\circ} \mathrm{C}$ in $2-\mu \mathrm{l}$ tubes $(11,33)$. The remaining cells were washed four additional times with choline washing solution (CWS: $170 \mathrm{mM}$ choline chloride, $1 \mathrm{mM} \mathrm{MgCl}$, $10 \mathrm{mM}$ Tris-Mops, $\mathrm{pH} 7.4$, at $4^{\circ} \mathrm{C}, 330$ mosM) for measurements of internal $\mathrm{Na}$ and $\mathrm{K}$ content by atomic absorption spectrometry $(10,11)$.

Measurement of maximal transport rates for $\mathrm{Na} / \mathrm{K}$ pump and $\mathrm{Na} /$ $\mathrm{K} / \mathrm{Cl}$ cotransport in mouse red cells. Maximized rates of $\mathrm{Na} / \mathrm{K}$ pump and $\mathrm{Na} / \mathrm{K} / \mathrm{Cl}$ cotransport activity were measured in cells containing equal amounts of $\mathrm{Na}$ and $\mathrm{K}$ by the nystatin technique, loading the cells with nystatin solution $(77 \mathrm{mM} \mathrm{NaCl}, 77 \mathrm{mM} \mathrm{KCl}$, and $55 \mathrm{mM} \mathrm{su}-$ crose) $(10,11)$. Under these conditions, in human red blood cells, the internal $\mathrm{Na}$ site of the $\mathrm{Na} / \mathrm{K}$ pump and the internal $\mathrm{Na}$ and $\mathrm{K}$ sites of the $\mathrm{Na} / \mathrm{K} / \mathrm{Cl}$ cotransport are saturated $(10,11) . \mathrm{Na} / \mathrm{K}$ pump activity was estimated as the ouabain-sensitive ( $1 \mathrm{mM}$ ouabain) fraction of $\mathrm{Na}$ efflux into a medium containing $165 \mathrm{mM}$ choline chloride and $10 \mathrm{mM}$ $\mathrm{KCl}$. This concentration of ouabain induces maximal inhibition of the $\mathrm{Na} / \mathrm{K}$ pump in mouse red cells $(10,11,32) . \mathrm{Na} / \mathrm{K} / \mathrm{Cl}$ cotransport activity was estimated as bumetanide-sensitive $(10 \mu \mathrm{M}) \mathrm{Na}$ efflux into a medium containing $174 \mathrm{mM}$ choline chloride and $1 \mathrm{mM}$ ouabain. $\mathrm{Na}$ efflux was calculated from the measurement of Na by atomic absorption spectrophotometry in cell-free supernatants. Na measurements were done after 5 and $25 \mathrm{~min}$ of incubation for $\mathrm{Na} / \mathrm{K}$ pump and after 5 and 40 min of incubation for $\mathrm{Na} / \mathrm{K} / \mathrm{Cl}$ cotransport activity.

Measurement of $\mathrm{K} / \mathrm{Cl}$ cotransport activity in mouse erythrocytes. Activity of $\mathrm{K} / \mathrm{Cl}$ cotransport in fresh mouse erythrocytes was measured as chloride- and volume-dependent $\mathrm{K}$ effluxes $(10,11)$. Net $\mathrm{K}$ efflux from fresh cells was measured in isotonic (340 mosM) and hypotonic $(260 \mathrm{mosM}) \mathrm{Na}$ media. $340 \mathrm{mosM}$ is considered isotonic for mouse red cells $(10,11)$. Volume- and chloride-dependent $\mathrm{K}$ fluxes were calculated as the differences between $\mathrm{K}$ efflux in chloride or in sulfonate hypotonic media. All flux media contained $1 \mathrm{mM} \mathrm{MgCl}$, $10 \mathrm{mM}$ glucose, $1 \mathrm{mM}$ ouabain, $0.01 \mathrm{mM}$ bumetanide, and $10 \mathrm{mM}$ Tris-MOPS, pH 7.4. K efflux was calculated after 5 and $25 \mathrm{~min}$ of incubation at $37^{\circ} \mathrm{C}$, measuring the amount of $\mathrm{K}$ present in cell-free supernatants by atomic absorption spectrophotometry $(10,11)$. When OA was used, cells were preincubated in the absence or presence of $100 \mathrm{nM}$ OA for $30 \mathrm{~min}$ at $37^{\circ} \mathrm{C}$ in high $\mathrm{K}$ medium $(10 \mathrm{mM} \mathrm{NaCl}, 160 \mathrm{mM}$ $\mathrm{KCl}, 1 \mathrm{mM} \mathrm{MgCl}, 10 \mathrm{mM}$ D-glucose, and $2.5 \mathrm{mM}$ potassium phosphate, $\mathrm{pH} 7.4$ ) at $2.5 \%$ hematocrit, and assays performed in the presence of OA. When staurosporine was used, cells were pretreated for $30 \mathrm{~min}$ at $37^{\circ} \mathrm{C}$ in high $\mathrm{K}$ medium in the absence or presence of $1 \mu \mathrm{M}$ staurosporine $(10,11)$. When $N$-ethylmaleimide (NEM) was used, cells were pretreated for $20 \mathrm{~min}$ in ice with $1 \mathrm{mM}$ NEM to maximize activation of $\mathrm{K} / \mathrm{Cl}$ cotransport $(35,36)$.

Statistical analysis. All values are expressed as means \pm SD. Data were compared by Student's $t$ test, or by ANOVA with Tukey's test for post-hoc comparison of the means when appropriate. Correlations were assessed by calculation of Pearson's correlation coefficient. 

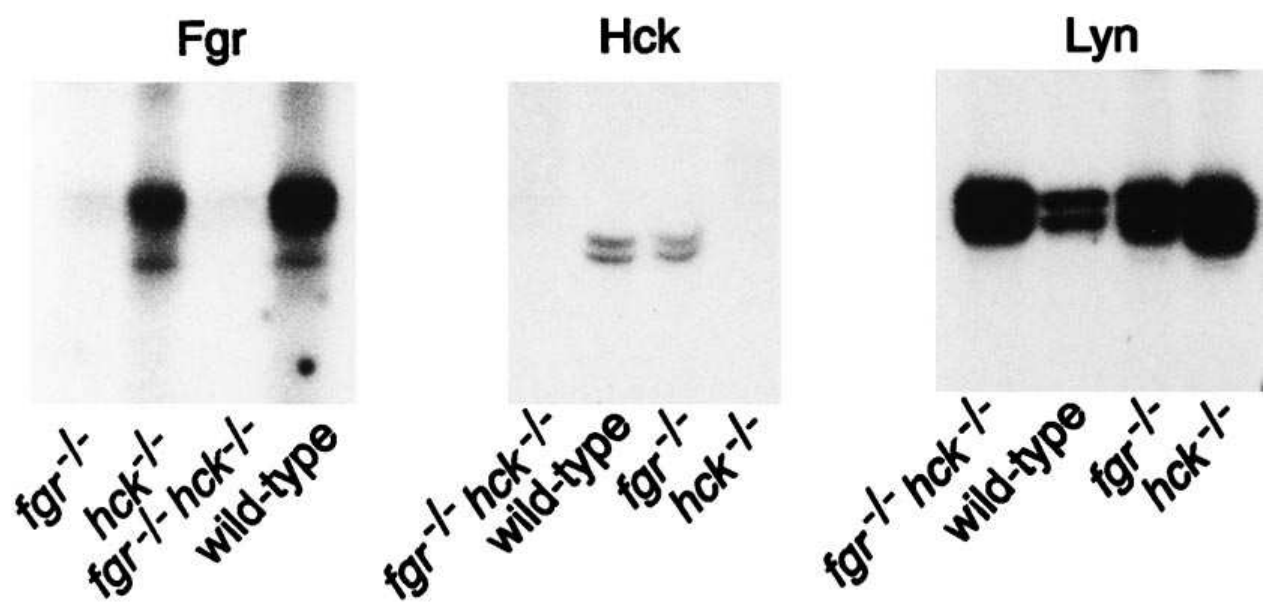

Figure 1. Analysis of Fgr, Hck, and Lyn autophosphorylating kinase activities in erythrocytes from wildtype and mutant mice. Erythrocytes were obtained as described in Methods and lysed with RIPA buffer. Immunoprecipitates were subjected to in vitro kinase assays as described in Methods. One representative autoradiogram is reported.

\section{Results}

Fgr and Hck are expressed in mouse erythrocytes. Since human erythrocytes contain the Src-family kinase Lyn (21), we examined murine red cells for the expression of two other Src-family kinases, Fgr and Hck. To this purpose, erythrocytes from wild-type, $\mathrm{fgr}^{-/-}, h c k^{-1-}$, and $\mathrm{fgr}^{-1-} h c k^{-/-}$mice were lysed and in vitro kinase assays were performed on anti-Fgr or -Hck immunoprecipitates. As shown in Fig. 1, no autophosphorylating kinase activity was detected in anti-Fgr immunoprecipitates from lysates of $\mathrm{fgr}^{-1-}$ or $\mathrm{fgr}^{-1-} h \mathrm{ck}^{-/-}$erythocytes; in contrast, autophosphorylated Fgr was clearly present in anti-Fgr immunoprecipitates from lysates of wild-type or $h c k^{-1-}$ erythrocytes. Likewise, autophosphorylated Hck was detected in anti-Hck immunoprecipitates from lysates of wild-type and $\mathrm{fgr}^{-1-}$, but not $h \mathrm{ck}^{-/-}$or $\mathrm{fgr}^{-/-} h \mathrm{k}^{-/-}$erythrocytes. We also examined whether the Lyn kinase is present in mouse erythrocytes. As shown in Fig. 1, we detected the Lyn doublet in all four strains of mice. Interestingly, the amount of immunoprecipitable Lyn kinase activity was increased in $\mathrm{fgr}^{-1-}, h \mathrm{ck}^{-/-}$, and $\mathrm{fgr}^{-1-} h \mathrm{ck}^{-/-}$ erythrocytes compared with wild-type cells. Similar results were obtained by comparing the Lyn kinase activity in wildtype and $h c k^{-1-}$ macrophages (29). Given that kinase activity is usually proportional to protein levels in resting cells, these data indicate that mouse erythrocytes express predominantly Lyn and Fgr, with Hck being found at a lower level. Expression of Fgr and Hck is not restricted to mouse cells since we detected expression of these two kinases in human erythrocytes as well (data not shown).

Hematologic data and cation content in erythrocytes of mutant mice. Table I summarizes the hematological data of wild- type, $\mathrm{fgr}^{-/-}, h c k^{-/-}$and $f \mathrm{gr}^{-/-} h c k^{-/-}$mice, and the red cell cation composition. We did not find any significant difference in the Hct value, the $\mathrm{Hb}$ level, or the number of reticulocytes in wild-type and mutant mice. In contrast, $\mathrm{fgr}^{-1-} \mathrm{hck}^{-/-}$doublemutant erythocytes exhibited a significant increase of $\mathrm{MCHC}$ and median density $\left(\mathrm{D}_{50}\right)$ compared with wild-type, and $\mathrm{fgr}^{-/-}$ and $h c k^{-l-}$ erythrocytes. Also, the Na content was similar in wild-type and mutant erythrocytes. However, $\mathrm{fgr}^{-1-} h \mathrm{ck}^{-/-}$ double-mutant erythrocytes exhibited a significant reduction in red cell $\mathrm{K}$ content compared with wild-type and $\mathrm{fgr}^{-1-}$ or $h c k^{-1-}$ erythrocytes. Increases in $\mathrm{MCHC}$ and $\mathrm{D}_{50}$, together with a decrease of $\mathrm{K}$ content, were suggestive of red cell dehydration in double-mutant erythrocytes.

Activity of the $\mathrm{Na} / \mathrm{K}$ pump and the $\mathrm{Na} / \mathrm{K} / \mathrm{Cl}$ cotransport in mutant erythrocytes. To compare membrane transport activity in wild-type and double-mutant erythrocytes, we examined the function of the $\mathrm{Na} / \mathrm{K}$ pump and the $\mathrm{Na} / \mathrm{K} / \mathrm{Cl}$ cotransport in wild-type and $f g r^{-1-} h c k^{-1-}$ erythrocytes (Table II). The activities of the $\mathrm{Na} / \mathrm{K}$ pump and the $\mathrm{Na} / \mathrm{K} / \mathrm{Cl}$ cotransport were similar in double-mutant and wild-type erythrocytes. We conclude that Fgr and Hck do not play any role in the regulation of these cation transport pathways.

$\mathrm{K} / \mathrm{Cl}$ cotransport activity in mutant erythrocytes. As increases in $\mathrm{MCHC}$ and $\mathrm{D}_{50}$ together with the decrease of $\mathrm{K}$ content we found in double-mutant erythrocytes were suggestive of red cell dehydration, we compared $\mathrm{K} / \mathrm{Cl}$ cotransport activity in wild-type and double-mutant erythrocytes (Fig. 2). Indeed, we found that ouabain- and bumetanide-insensitive $\mathrm{K}$ efflux ( $\mathrm{K} / \mathrm{Cl}$ cotransport) was significantly increased in $\mathrm{fgr}^{-/-} h \mathrm{ck}^{-/-}$ double-mutant compared with wild-type erythrocytes.

Table I. Hematological Data and Cation Content in Wild-type and Mutant Mouse Red Cells

\begin{tabular}{|c|c|c|c|c|c|c|c|}
\hline & Hct & $\mathrm{Hb}$ & $\mathrm{MCHC}$ & Retics & $\mathrm{D}_{50}$ & $\mathrm{Na}^{+}$ & $\mathrm{K}^{+}$ \\
\hline & $\%$ & $g / d l$ & $g / d l$ & $\%$ & & $\mathrm{mmol} / \mathrm{kg} \mathrm{Hb}$ & $\mathrm{mmol} / \mathrm{Kg} \mathrm{Hb}$ \\
\hline Wild-type & $44.3 \pm 1.7$ & $15.1 \pm 0.8$ & $30.2 \pm 1.4$ & $2.4 \pm 0.4$ & $1.093 \pm 0.001$ & $55.3 \pm 4.2$ & $429.7 \pm 11.3$ \\
\hline $\mathrm{fgr}^{-1-} \mathrm{hck}^{-/-}$ & $44.5 \pm 1.8$ & $14.3 \pm 1.2$ & $33.1 \pm 0.8^{*}$ & $1.8 \pm 0.3$ & $1.115 \pm 0.002^{\ddagger}$ & $56.4 \pm 3.1$ & $354.7 \pm 10.6^{\ddagger}$ \\
\hline$h c k^{-1-}$ & $45.2 \pm 0.7$ & $14.8 \pm 0.5$ & $31.2 \pm 0.6$ & $2.1 \pm 0.2$ & $1.095 \pm 0.002$ & $52.3 \pm 6.1$ & $444.1 \pm 16.9$ \\
\hline$f g r^{-1-}$ & $44.3 \pm 1.7$ & $14.9 \pm 1.1$ & $30.2 \pm 1.4$ & $2.5 \pm 0.8$ & $1.094 \pm 0.001$ & $54.9 \pm 1.2$ & $437.7 \pm 9.3$ \\
\hline
\end{tabular}

Values are means \pm SD $(n=12) . * P<0.05$, and ${ }^{\ddagger} P<0.005$ compared with wild-type mice. 
Table II. Na/K Pump and Na/K/Cl Cotransport Activities in Wild-type and $\mathrm{fgr}^{-/-} \mathrm{hck}^{-/-}$Mouse Red Cells

\begin{tabular}{|c|c|c|}
\hline & \multicolumn{2}{|c|}{ Na efflux } \\
\hline & Wild-type & $f g r^{-1-} h c k^{-1-}$ \\
\hline & \multicolumn{2}{|c|}{ nmol/liter cell per $h$} \\
\hline \multicolumn{3}{|l|}{$\mathrm{Na} / \mathrm{K}$ pump } \\
\hline Control & $25.8 \pm 4.2(3)$ & $27.1 \pm 5.2(3)$ \\
\hline + Quabain (1 mM) & $7.3 \pm 1.2(3)$ & $8.8 \pm 2.1(3)$ \\
\hline Quabain sensitive & $18.5 \pm 2.7(3)$ & $18.3 \pm 3.9(3)$ \\
\hline \multicolumn{3}{|l|}{$\mathrm{Na} / \mathrm{K} / \mathrm{Cl}$ cotransport } \\
\hline Control & $5.6 \pm 2.2(3)$ & $4.9 \pm 1.8(3)$ \\
\hline+ Bumetanide $(10 \mu \mathrm{M})$ & $2.4 \pm 0.7(3)$ & $2.8 \pm 0.3(3)$ \\
\hline Bumetanide sensitive & $3.2 \pm 1.6(3)$ & $2.1 \pm 1.4(3)$ \\
\hline
\end{tabular}

Data represent means \pm SD of the number of determinations given in parenthesis. $\mathrm{Na} / \mathrm{K}$ pump and $\mathrm{Na} / \mathrm{K} / \mathrm{Cl}$ cotransport were measured as $\mathrm{Na}$ efflux, as described in Methods.

Effect of bleeding on $\mathrm{K} / \mathrm{Cl}$ cotransport activity in mutant erythrocytes. $\mathrm{K} / \mathrm{Cl}$ cotransport activity is dependent on cell age as indicated by the evidence that, in human cells, the system is active in reticulocytes and declines in mature erythrocytes (3-6). We therefore addressed whether an increase of

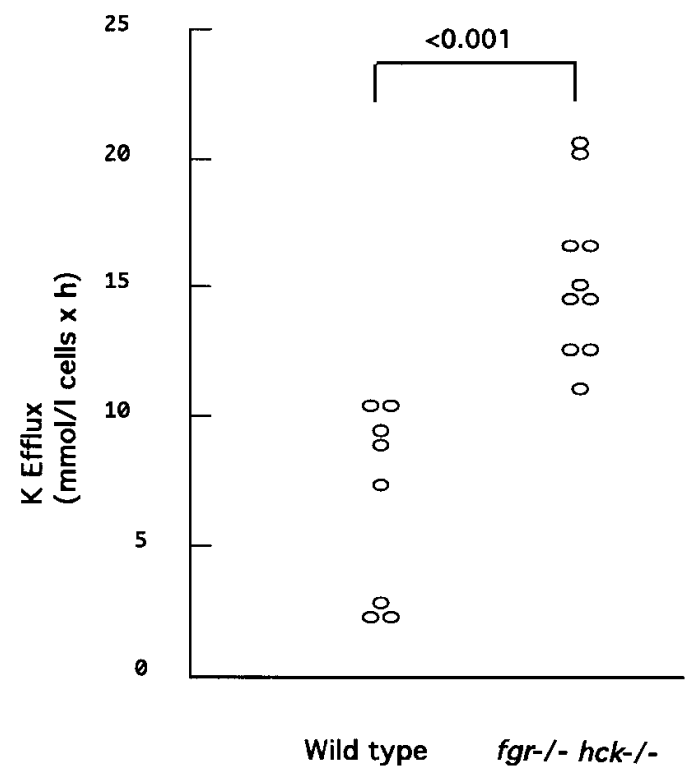

Figure 2. $\mathrm{K} / \mathrm{Cl}$ cotransport activity in wild-type and $\mathrm{fgr}^{-/-} h \mathrm{ck}^{-/-}$double-mutant erythrocytes. $\mathrm{K} / \mathrm{Cl}$ cotransport was measured and statistical analysis performed as descibed in Methods. Means $\pm \mathrm{SD}$ of $\mathrm{K} / \mathrm{Cl}$ cotransport activity in the experiments reported was: wild-type, $6.67 \pm 3.66 ; \mathrm{fgr}^{-1-} \mathrm{hck}^{-1-}, 15.42 \pm 3.10$.
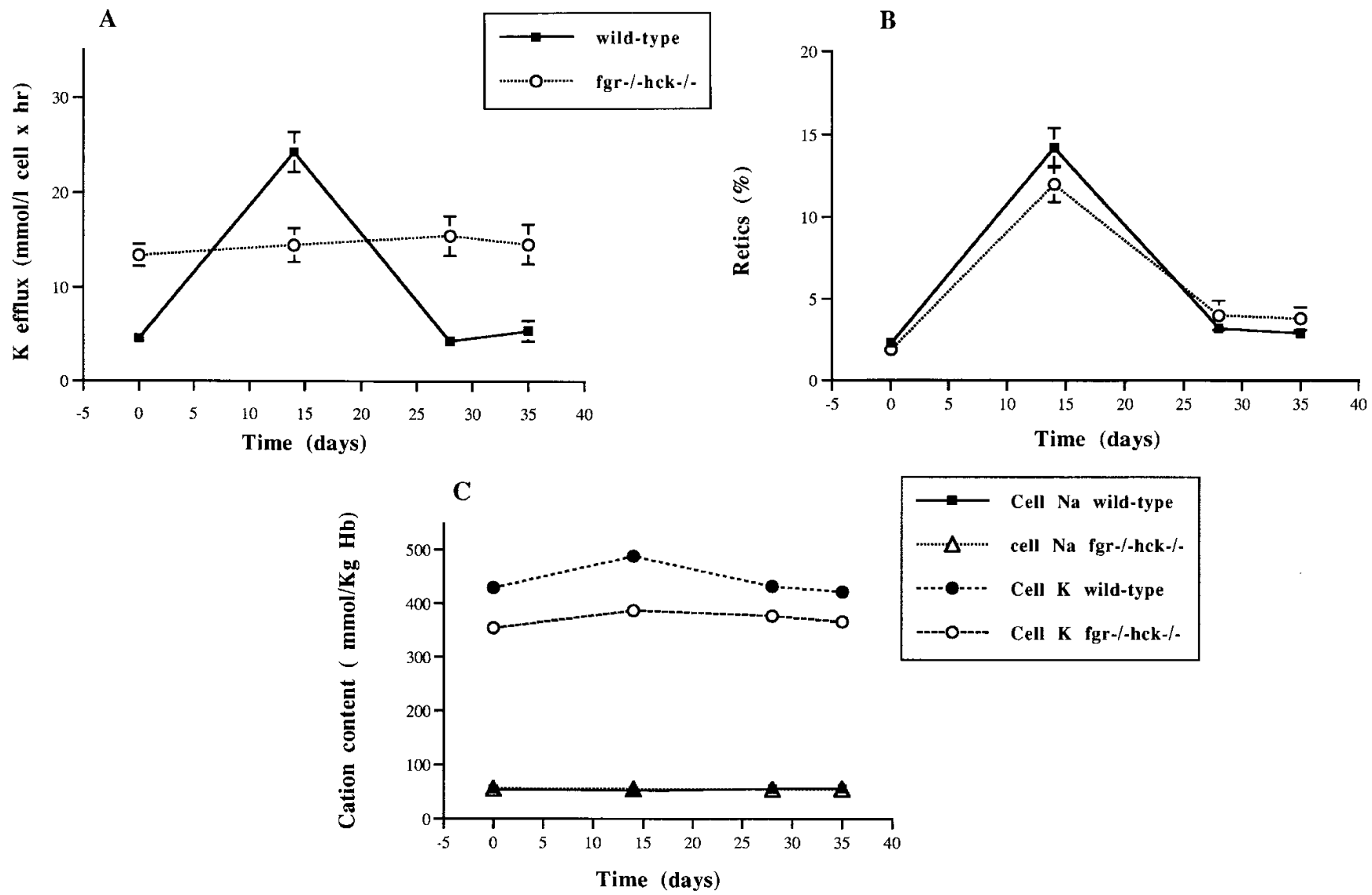

Figure 3. Effect of multiple bleeding on $\mathrm{K} / \mathrm{Cl}$ cotransport activity $(A)$, reticulocyte count $(B)$, and intracellular cation content $(C)$ of wild-type and $\mathrm{fgr}^{-1-} h \mathrm{ck}^{-/-}$double-mutant erythrocytes. Mean results \pm SD of six independent experiments are reported. In $C$, error bars are within the symbols and not visible. Symbols indicating cell Na content of wild-type and $f \mathrm{gr}^{-l-} h c k^{-1-}$ double-mutant erythrocytes are superimposed because values were equal. The difference of $\mathrm{K}$ content at $14 \mathrm{~d}$ after beeding vs. day 0 (baseline) was significantly different $(P<0.05)$ in wild-type erythrocytes. 


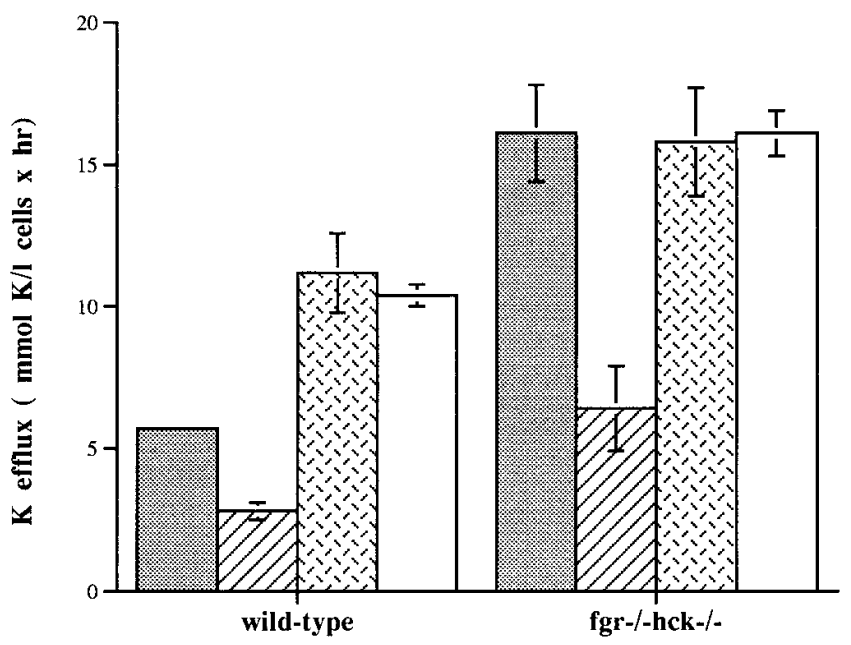

Figure 4. Effect of OA, staurosporine, and NEM on $\mathrm{K} / \mathrm{Cl}$ cotransport of wild-type and $\mathrm{fgr}^{-1-}-h \mathrm{ck}^{-/-}$double-mutant erythrocytes. Erythrocytes were treated with the indicated inhibitor as described in Methods. Data are expressed as activity of $\mathrm{K} / \mathrm{Cl}$ cotransport in the absence or presence of the indicated inhibitor. Mean results $\pm \mathrm{SD}$ of four independent experiments are reported. 㒛, $\mathrm{K} / \mathrm{Cl} \cot ; \square, \mathrm{K} / \mathrm{Cl} \cot +\mathrm{OA}$; 图, $\mathrm{K} / \mathrm{Cl} \cot +$ staurosporine; $\square, \mathrm{K} / \mathrm{Cl} \cot +\mathrm{NEM}$.

reticulocytes in $\mathrm{fgr}^{-/-} h \mathrm{ck}^{-/-}$double-mutant mice affects the activity of $\mathrm{K} / \mathrm{Cl}$ cotransport. Reticulocytosis was induced with a bleeding protocol that reduced Hct to values below $40 \%$, and substantially increased the reticulocyte count (Fig. 3). We did not find any difference in the bleeding-induced increase of reticulocytes in wild-type or $\mathrm{fgr}^{-/-} \mathrm{hck}^{-/-}$double-mutant mice. The increase in reticulocyte levels was associated with a shift in the phthalate density ditribution curve (data now shown). No significant change of red cell $\mathrm{Na}$ content in wild-type and $\mathrm{fgr}^{-/} h \mathrm{ck}^{-/-}$ erythrocytes was observed in this study (Fig. 3). Erythrocyte K content increased significantly in wild-type mice after the bleeding procedure, while no change was evident for $\mathrm{fgr}^{-/} h \mathrm{ck}^{-/-}$cells (see Fig. 3 legend). Analysis of $\mathrm{K} / \mathrm{Cl}$ cotransport activity showed that this increased substantially in wild-type erythrocytes after bleeding, and this correlated with an increase of young red cells (Fig. 3). In contrast, after repetitive bleeding, the $\mathrm{K} / \mathrm{Cl}$ cotransport activity in $\mathrm{fgr}^{-/-} \mathrm{hck}^{-/-}$double-mutant erythrocytes did not further increase.

Effect of okadaic acid, staurosporine, and NEM on $\mathrm{K} / \mathrm{Cl}$ cotransport of mutant erythrocytes. The capability of Fgr and Hck to regulate $\mathrm{K} / \mathrm{Cl}$ cotransport can be either direct or indirect. Recent studies have shown that staurosporine-sensitive protein kinase(s) inhibit and OA-sensitive protein phosphatase(s) enhance $\mathrm{K} / \mathrm{Cl}$ cotransport (see references 13, 15-17, 19, 20, 37). Therefore, we compared the effect of these inhibitors on $\mathrm{K} / \mathrm{Cl}$ cotransport activity of wild-type and double-mutant erythrocytes (Fig. 4). In accord with previous studies (10, 11, 17), we found that staurosporine enhanced $\mathrm{K} / \mathrm{Cl}$ cotransport activity in wild-type erythrocytes. However, we did not find any enhancing effect of this drug on $\mathrm{K} / \mathrm{Cl}$ cotransport of $\mathrm{fgr}^{-/-}$ $h c k^{-1-}$ double-mutant erythrocytes. The use of the protein phosphatase inhibitor $\mathrm{OA}$ allowed us to confirm previous studies showing an inhibitory effect of this drug on $\mathrm{K} / \mathrm{Cl}$ cotransport $(15,16,19)$. In fact, as shown in Fig. 4, OA inhibited $\mathrm{K} / \mathrm{Cl}$ cotransport in wild-type, as well as $\mathrm{fgr}^{-/-} h \mathrm{ck}^{-/-}$ erythrocytes. The evidence that $\mathrm{OA}$ also inhibited $\mathrm{K} / \mathrm{Cl}$ cotransport in $\mathrm{fgr}^{-/-} \mathrm{hck}^{-/-}$double-mutant erythrocytes suggests that, even in the absence of Fgr and Hck, protein phosphatases are required to maintain the transporter in a high-activity state.

We also analyzed $\mathrm{K} / \mathrm{Cl}$ cotransport activity in the presence of NEM, an agent that has been shown to active $\mathrm{K} / \mathrm{Cl}$ cotransport activity in human, sheep, and mouse erythrocytes $(1,2,35$, 36, 38). As shown in Fig. 4, NEM increased $\mathrm{K} / \mathrm{Cl}$ cotransport activity in wild-type mouse erythrocytes and its effect was comparable with that of staurosporine. In contrast, NEM had no enhancing effect on $\mathrm{K} / \mathrm{Cl}$ cotransport activity of $\mathrm{grr}^{-/-} h \mathrm{ck}^{-/-}$ double-mutant erythrocytes.

\section{Discussion}

In this report, we demonstrate the presence of Fgr and Hck, as well as Lyn, in mouse erythrocytes. Together with the recent identification of Syk and Lyn in human red cells (21), our findings point to an unexpected role for cytoplasmic tyrosine kinases in the regulation of erythrocyte functions. Erythrocyte expression of these Src-family tyrosine kinases does not seem to be species restricted since Lyn, Hck, and Fgr are also found in human red cells (21 and L. Fumagalli, L. De Franceschi, and G. Berton, unpublished observations). These findings reinforce the knowledge accumulated in the last few years that Srcfamily kinases participate in cell functions totally unrelated to regulation of cell growth and gene transcription. For example, Src-family kinases have been implicated in the generation of signals involved in the rearrangement of the cytoskeleton in aggregating platelets (reviewed in reference 39). Moreover, integrin-dependent activation of selective neutrophil functions involves Src-family kinases $(30,31)$.

To test directly whether Fgr and Hck play functional roles in modulating red cell membrane cation transport pathways, we analyzed erythrocytes from $\mathrm{fgr}^{-/-}, h \mathrm{ck}^{-/-}$, and $\mathrm{fgr}^{-1-} \mathrm{hck}^{-/-}$ mice. Previous analysis of these mice revealed that the doublemutant animals are susceptible to L. monocytogenes infection (28), and double-mutant neutrophils are defective in functions dependent on integrin-adhesion (30). We found that erythrocytes from $\mathrm{fgr}^{-1-} h \mathrm{ck}^{-1-}$ mice were characterized by water and $\mathrm{K}$ loss when compared with either wild-type, $\mathrm{fgr}^{-1-}$, or $h \mathrm{ck}^{-/-}$ cells (Table I). Since the cell Na content was similar in erythrocytes from wild-type and mutant mice (Table I), the decrease of $\mathrm{K}$ content in $\mathrm{fgr}^{-1-} h c k^{-1-}$ erythrocytes is likely due to an activation of the $\mathrm{K} / \mathrm{Cl}$ cotransport. Moreover, we did not find any difference in the activity of the $\mathrm{Na} / \mathrm{K}$ pump and the $\mathrm{Na} / \mathrm{K}$ / $\mathrm{Cl}$ cotransport in wild-type and mutant mice erythrocytes (Table II). Analysis of $\mathrm{K} / \mathrm{Cl}$ cotransport activity provided direct evidence of activation of the transporter in $\mathrm{fgr}^{-1-} \mathrm{hck}^{-/-}$erythrocytes (Fig. 2). Previous studies indicated that these kinases serve at least partially redundant functions in innate immunity and adhesion-dependent neutrophil activation $(29,30)$. The results presented in this paper are in line with these findings; in fact, we found clear phenotypic alterations (i.e., red cell water and $\mathrm{K}$ loss) only in erythrocytes with deficiency of both kinases.

Cell age represents a well known factor influencing the expression of $\mathrm{K} / \mathrm{Cl}$ cotransport activity $(5,6)$. In wild-type mice, when the reticulocyte level was increased as a consequence of repetitive bleeding, the circulating red cells had an increased cation content (Fig. 3). Increased total cation content in young red cells has been demonstrated in sheep and rabbit red cells and depends primarily on an increase of $\mathrm{K}$ content $(8,40)$. In wild-type mice erythrocytes, reticulocytosis was associated 


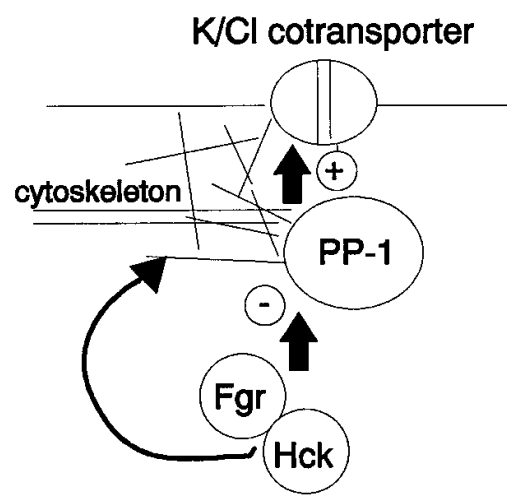

Figure 5. Hypothetical mechanisms of regulation of erythrocyte $\mathrm{K} / \mathrm{Cl}$ cotransport. The proposed model is based on evidence suggesting that a protein kinase-regulated phosphatase activates the $\mathrm{K} / \mathrm{Cl}$ cotransporter (see references $13,15-17$, 19, 20, 37). Data have been presented indicating that the phosphatase activating the

$\mathrm{K} / \mathrm{Cl}$ cotransporter is represented by the serine/threonine protein phosphatase type 1 (PP-1) $(19,20,37)$. Our findings that the $\mathrm{K} / \mathrm{Cl}$ cotransporter is activated in $\mathrm{fgr}^{-/-} h \mathrm{ck}^{-/-}$double-mutant erythrocytes would suggest that Fgr and Hck inhibit the regulatory phosphatase. A critical role of this phosphatase in activating the $\mathrm{K} / \mathrm{Cl}$ cotransporter is strengthened by our finding that $\mathrm{OA}$ inhibits $\mathrm{K} / \mathrm{Cl}$ cotransport in wild-type as well as $\mathrm{fgr}^{-1-} h \mathrm{ck}^{-1-}$ double-mutant erythrocytes; i.e., in cells in which the putative constraint exerted by Src-family kinases on the phosphatase activity is lacking. The lack of effect of staurosporine and NEM on $\mathrm{K} / \mathrm{Cl}$ cotransport of $f \mathrm{gr}^{-/-} h c k^{-/-}$double-mutant erythrocytes can be explained hypothesizing that the target of staurosporine and NEM in wild-type erythrocytes is represented by Fgr and Hck (see text). It is known that staurosporine also inhibits tyrosine kinase activities (see text). An alternative explanation of our findings is that Fgr and Hck regulate the assembly of red cell cytoskeleton. Src-family kinases are clearly implicated in regulation of the rearrangement of the cytoskeleton in hematopoietic cells (see text). The cytoskeleton might regulate the $\mathrm{K} / \mathrm{Cl}$ cotransporter and/or the regulatory phosphatase activities, and alterations in cytoskeleton dynamics in $\mathrm{frr}^{-1-} \mathrm{hck}^{-1-}$ double-mutant erythrocytes might underlie enhanced $\mathrm{K} / \mathrm{Cl}$ cotransport. The evidence that erythrocytes from single-mutant $\mathrm{fgr}^{-1-}$ or $h c k^{-1-}$ mice do not display any alteration of $\mathrm{K}$ content, $\mathrm{MCHC}$, or $\mathrm{D}_{50}$ suggests that Fgr and Hck also play an overlapping function in erythrocytes. This is in line with studies with macrophages (29) and neutrophils (30)

with a significant increase in the activity of the $\mathrm{K} / \mathrm{Cl}$ cotransport (Fig. 3). In contrast, an increase in the percentage of reticulocytes did not result in any substantial change in the $\mathrm{K}$ content and $\mathrm{K} / \mathrm{Cl}$ cotransport activity of $f \mathrm{gr}^{-1-} h \mathrm{ck}^{-/-}$erythrocytes. In addition, experiments with wild-type mice showed that $\mathrm{K} / \mathrm{Cl}$ cotransport activity declined after several days from bleeding (i.e., in coincidence with the red cell differentiation); in contrast, in $\mathrm{frr}^{-/-} h \mathrm{ck}^{-/-}$erythrocytes it remained fairly constant independently of the state of cell differentiation (Fig 3). These findings suggest that cell age might affect $\mathrm{K} / \mathrm{Cl}$ cotransport by modulating Fgr and Hck kinase activity. However, we cannot exclude that deficiency of Fgr and Hck results in additional cation transport alterations in young red cells.

One of the models advanced to explain regulation of $\mathrm{K} / \mathrm{Cl}$ cotransport activity attributes an essential role to phosphorylation/dephosphorylation reactions in shifting the $\mathrm{K} / \mathrm{Cl}$ cotransporter to a low or high activity state (see reference 20). According to this model, an OA-sensitive phosphatase activity is required to maintain the transporter in a high activity state, and the activity of this phosphatase is negatively regulated by a staurosporine-sensitive kinase. Indeed, stimulation of $\mathrm{K} / \mathrm{Cl}$ cotransport by cell swelling or oxidants has been shown to de- pend on activation of a serine/threonine protein phosphatase that, on the basis of its sensitivity to inhibition with OA and calyculin $\mathrm{A}$, and its possible membrane localization, has been identified as the protein phosphatase type $1(19,20)$. This has been validated by recent reconstitution experiments in erythrocyte ghosts (37). Interestingly, we found that $\mathrm{OA}$ inhibited $\mathrm{K} / \mathrm{Cl}$ cotransport activity in wild-type and $f \mathrm{gr}^{-/-} h \mathrm{ck}^{-/-}$erythrocytes (Fig. 4). According to the model attributing a critical role to a phosphatase activity (i.e., protein phosphatase type 1) in regulating $\mathrm{K} / \mathrm{Cl}$ cotransport, our findings would suggest that this phosphatase might be negatively regulated by Fgr and Hck (Fig. 5). Therefore, in $f g r^{-1-} h c k^{-1-}$ double-mutant erythrocytes this phosphatase would be constitutively active, resulting in high $\mathrm{K} / \mathrm{Cl}$ cotransport activity. If so, one could anticipate that inhibition of this phosphatase by OA should decrease $\mathrm{K} / \mathrm{Cl}$ cotransport even in $f \mathrm{gr}^{-1-} h \mathrm{ck}^{-/-}$double-mutant erythrocytes. Indeed, the results reported in Fig. 4 show that this was the case, thus suggesting the possibility that Fgr and Hck act regulating the activity of the OA-sensitive phosphatase. The phosphatase shifting the $\mathrm{K} / \mathrm{Cl}$ cotransporter to a high activity state was suggested to be negatively regulated by a staurosporinesensitive kinase (20). Indeed, staurosporine enhances $\mathrm{K} / \mathrm{Cl}$ cotransport activity and this finding was explained as due to inhibition of the constraint the staurosporine-sensitive kinase exerts on the activity of the phosphatase (20). It is of interest that we confirmed a stimulatory effect of staurosporine on $\mathrm{K} / \mathrm{Cl}$ cotransport activity of wild-type mouse erythrocytes, but we did not find any effect of the drug on $\mathrm{K} / \mathrm{Cl}$ cotransport activity of $\mathrm{fgr}^{-/-} h \mathrm{ck}^{-/-}$mouse erythrocytes (Fig. 4). This finding suggests that Fgr and Hck might be the target of staurosporine and, in erythrocytes lacking the two kinases, the drug cannot increase $\mathrm{K} / \mathrm{Cl}$ cotransport activity. It should be pointed out that staurosporine has only a limited selectivity as an inhibitor of protein kinases and it has also been shown to inhibit tyrosine kinases, including Src (41-44). It is of interest that NEM, which has been shown to enhance $\mathrm{K} / \mathrm{Cl}$ cotransport activity in erythrocytes from different species $(1,2,35,36,38$, and Fig. 4) did not enhance $\mathrm{K} / \mathrm{Cl}$ cotransport activity in $\mathrm{fgr}^{-/-}$ $h c k^{-1-}$ double-mutant erythrocytes. The simplest explanation of this finding is that Src-family kinases are the target of NEM. However, we cannot exclude that the lack of effect of NEM, and possibly staurosporine itself, is simply due to the fact that the high $\mathrm{K} / \mathrm{Cl}$ cotransport activity of $\mathrm{gr}^{-l-} h \mathrm{ck}^{-/-}$doublemutant erythrocytes cannot be boosted further.

On the basis of the current models of regulation of $\mathrm{K} / \mathrm{Cl}$ cotransport (20), our inhibitory studies would suggest that Fgr and Hck act by inhibiting an OA-sensitive phosphatase that activates $\mathrm{K} / \mathrm{Cl}$ cotransport (Fig. 5). A possible role of Fgr and Hck in regulating the OA-sensitive serine/threonine phosphatases 1 and $2 \mathrm{~A}$ is supported by accumulating data demonstrating the existence of a cross-talk between tyrosine kinases and serine/threonine phosphatase activities (45-48). It is of great interest that phosphatases 1 and $2 \mathrm{~A}$ have been shown to be substrates of $\mathrm{p} 60^{\mathrm{v}-\mathrm{src}}$ and $\mathrm{p} 56^{\mathrm{lck}}$, as well as receptor tyrosine kinases $(45,47)$. Importantly, tyrosine phosphorylation of protein phosphatases 1 (45) and 2A (47) results in inhibition of their activity. These data give ground to our findings suggesting a negative regulatory role of Fgr and Hck on one phosphatase (i.e., protein phosphatase 1) responsible for activation of $\mathrm{K} / \mathrm{Cl}$ cotransport.

The capability of Fgr and Hck to negatively regulate a phosphatase affecting $\mathrm{K} / \mathrm{Cl}$ cotransport may well be indirect 
(Fig. 5). Accumulating data point to an essential role for Srcfamily kinases in reorganizing the cytoskeleton in hematopoietic cells. Fgr and Hck are required to promote the formation of an actin-based cytoskeleton triggered by integrins in neutrophils (30), as well as macrophages (C.A. Lowell and G. Berton, unpublished observations). Interestingly, recent findings pointed to an important role for the cytoskeleton in regulating ion transport. Erythrocyte cytoskeletal dysfunctions result in an increased cation permeability (49). Mutations in the cytoskeletal protein adducin result in alterations of actin assembly, as well as ion transport in epithelial cells and erythrocytes (see reference 50). Therefore, $\mathrm{K} / \mathrm{Cl}$ cotransport alterations in $\mathrm{fgr}^{-l-}$ $h c k^{-/-}$double-mutant mice might be secondary to cytoskeletal dysfunctions. Alterations in the assembly of the cell cytoskeleton might cause membrane dysfunctions affecting $\mathrm{K} / \mathrm{Cl}$ cotransport. Alternatively, the cell cytoskeleton might regulate the function of the phosphatase implicated in activation of the $\mathrm{K} / \mathrm{Cl}$ cotransporter.

The data presented in this report are the first to implicate Src-family kinases in regulation of erythrocyte membrane cation transport. Besides providing clues to understand the role of tyrosine phosphorylation in regulating $\mathrm{K} / \mathrm{Cl}$ cotransport, they extend the array of cell responses regulated by Src-family kinases.

\section{Acknowledgments}

The authors thank Mrs. Angela Siciliano for excellent technical assistance.

This work was supported by grants from University of Verona (Fondi 60\%), the Italian Association for Cancer Research (AIRC), and National Institutes of Health (DK-50627 to C.A. Lowell).

\section{References}

1. Lauf, P.K., J. Bauer, N.C. Adragna, H. Fujise, A.M.M. Zade-Oppen, K. Hai-Ryu, and E. Delpire. 1992. Erythrocyte K/Cl cotransport: properties and regulation. Am. J. Physiol. 263:C917-C932.

2. Brugnara, C. 1994. Cation homeostasis. In Sickle Cell Disease: Basic Principles and Clinical Practice. S.H. Embury, R.P. Hebbel, N. Mohandas, and M.H. Steinberg, editors. Raven Press, Ltd., New York. 173-194.

3. Brugnara, C. 1989. Characteristics of the volume and chloride dependent $\mathrm{K}$ transport in human erythrocytes homozygous for hemoglobin C. J. Membr. Biol. 111:69-81.

4. Brugnara, C., H.F. Bunn, and D.C. Tosteson. 1989. Ion content and transport and the regulation of volume in sickle cells. Ann. NY. Acad. Sci. 565: 96-103.

5. Brugnara, C., T. Van Ha, and D.C. Tosteson. 1988. Properties of K transport in resealed human erythrocyte ghosts. Am. J. Physiol. 255:C346-C356.

6. Canessa, M., M.E. Fabry, N. Blumenfeld, and R.L. Nagel. 1987. Volume stimulated $\mathrm{Cl}$ dependent $\mathrm{K}$ efflux is highly expressed in young human red cells containing normal hemoglobin or Hb S. J. Membr. Biol. 97:97-105.

7. Olivieri, O., L. De Franceschi, M.D. Capellini, D. Girelli, R. Corrocher, and C. Brugnara. 1994. Oxidative damage and erythrocyte membrane transport abnormalities in thalassemias. Blood. 84:315-320.

8. Brugnara, C., and L. De Franceschi. 1993. Effect of cell age and phenylhydrazine on the cation transport properties. J. Cell. Physiol. 154:271-280.

9. Hall, A.C., and J.C. Ellory. 1986. Evidence for the presence of a volumesensitive $\mathrm{K} / \mathrm{Cl}$ cotransport in "young" human red cells. Biochim. Biophys. Acta. 858:317-320.

10. Armsby, C.C., C. Brugnara, and S.L. Alper. 1995. Cation transport in mouse erythrocytes: role of $\mathrm{K} / \mathrm{Cl}$ cotransport in regulatory volume decrease. Am. J. Physiol. 268:C894-C902.

11. De Franceschi, L., Y. Beuzard, and C. Brugnara. 1995. Sulfhydryl oxidation and activation of red cell $\mathrm{K} / \mathrm{Cl}$ cotransport in the transgenic SAD mouse. Am. J. Physiol. 268:C899-C906.

12. Olivieri, O., M. Bonollo, S. Friso, D. Girelli, R. Corrocher, and L. Vettore. 1993. Activation of $\mathrm{K} / \mathrm{Cl}$ cotransport in human erythrocytes exposed to oxidative agent. Biochim. Biophys. Acta. 1176:37-42.

13. Jennings, M.L., and N. Al-Rohil. 1990. Kinetics of activation and inacti- vation of swelling-stimulated $\mathrm{K} / \mathrm{Cl}$ transport. The volume sensitive parameter is the rate constant for inactivation. J. Gen. Physiol. 95:1021-1040.

14. Dunham, P.B. 1990. K/Cl cotransport in mammalian erythrocytes. In Regulation of Potassium Transport Across Biological Membranes. L. Reuss, J.M. Russel, and G. Szabo, editors. University of Texas Press, Austin, TX. 331-360.

15. Jennings, M.L., and R.K. Schulz. 1991. Okadaic acid inhibition of K/Cl cotransport. Evidence that protein dephosphorilation is necessary for activation of transport by either cell swelling or N-ethylmaleimide. J. Gen. Physiol. 97:799-818.

16. Kaji, D.M., and Y. Tsukitani. 1991. Role of protein phosphatase in activation of $\mathrm{K} / \mathrm{Cl}$ cotransport in human erythrocytes. Am. J. Physiol. 260:C178C182.

17. Bize, I., and P.B. Dunham. 1994. Staurosporine, a protein kinase inhibitor, activates $\mathrm{K} / \mathrm{Cl}$ cotransport in LK sheep eryhtrocytes. Am. J. Physiol. 266: C759-C770.

18. Kaji, D.M. 1986. Volume sensitive K transport in human erythrocytes. $J$. Gen. Physiol. 88:719-738.

19. Starke, L.C., and M.L. Jennings. 1993. K-Cl cotransport in rabbit red cells: further evidence for regulation by protein phosphatase 1. Am. J. Physiol. 264:C118-C124

20. Bize, I., and P.B. Dunham. 1995. $\mathrm{H}_{2} \mathrm{O}_{2}$ activates red blood cell K-C cotransport via stimulation of a phosphatase. Am. J. Physiol. 269:C849-C855.

21. Harrison, M.L., C.C. Isaacson, D.L. Burg, R.L. Geahlen, and P.S. Low. 1994. Phosphorylation of human erythrocyte band 3 by endogenous $\mathrm{p} 72^{\text {syk }} . J$. Biol. Chem. 269:955-959.

22. Bolen, J.B., R.B. Rowley, C. Spana, and A.Y. Tsygankov. 1992. The Src family of tyrosine protein kinases in hemopoietic signal transduction. FASEB J. 6:3403-3409.

23. Bolen, J.B. 1995. Protein tyrosine kinases in the initiation of antigen receptor signaling. Curr. Op. Immunol. 7:306-311.

24. Lowell, C.A., and P. Soriano. 1996. Knockouts of Src-family kinases: stiff bones, wimpy T cells, and bad memories. Genes Dev. 10:1845-1857.

25. Qintrell, N., R. Lebo, H. Varmus, J.M. Bishop, M.J. Pettenati, M.M. Le Beau, M.O. Diaz, and J.D. Rowley. 1987. Identification of a human gene (HCK) that encodes a protein-tyrosine kinase and is expressed by hemopoietic cells. Mol. Cell. Biol. 7:2267-2275.

26. Yamanashi, Y., S. Mori, M. Yoshida, T. Kishimoto, K. Inoue, T. Yamamoto, and K. Toyoshima. 1989. Selective expression of a protein-tyrosine kinase, $\mathrm{p} 53^{\mathrm{lyn}}$, in hematopoietic cells and association with production of human T-cell lymphotropic virus type I. Proc. Natl. Acad. Sci. USA. 86:6538-6542.

27. Link, D.C., and M. Zutter. 1995. The proto-oncogene $c$-fgr is expressed in normal mantle zone B lymphocytes and is developmentally regulated during myelomonocytic differentiation in vivo. Blood. 85:472-479.

28. Wechsler, R.J., and J.G. Monroe. 1995. src-family tyrosine kinase p55 $5^{\text {fgr }}$ is expressed in murine splenic B cells and is activated in response to antigenreceptor cross-linking. J. Immunol. 154:3234-3244.

29. Lowell, C.A., P. Soriano, and H.E. Varmus. 1994. Functional overlap in the $\operatorname{src}$ gene family: inactivation of $h c k$ and $f g r$ impairs natural immunity. Gene Dev. 8:387-398.

30. Lowell, C.A., L. Fumagalli, and G. Berton. 1996. Deficiency of Src family kinases p59/61 $1^{\text {hck }}$ and p $58^{\text {c-fgr }}$ results in defective adhesion-dependent neutrophil functions. J. Cell Biol. 133:895-910.

31. Berton, G., L. Fumagalli, C. Laudanna, and C. Sorio. 1994. $\beta 2$ integrindependent protein tyrosine phosphorylation and activation of the Fgr protein tyrosine kinase in human neutrophils. J. Cell Biol. 126:1111-1121.

32. Benos, I., and D.C. Tosteson. 1980. Cation movements across mouse red blood cells. Biochim. Biophys. Acta. 601:167-179.

33. De Franceschi, L., P. Rouyer-Fessard, S.L. Alper, H. Jouault, C. Brugnara, and Y. Beuzard. 1966. Combination therapy of erythropoietin, hydroxyurea and clotrimazole in a $\beta$ thalassemic mouse: a model for human therapy. Blood. 87:1188-1195.

34. Danon, D., and Y. Marikovsky. 1964. Determination of density distribution of red cell population. J. Clin. Lab. Med. 64:668-674.

35. Lauf, P.K., and N.C. Adragna. 1995. Temperature-induced functional deocclusion of thiols inhibitory for sheep erythrocyte $\mathrm{K}-\mathrm{Cl}$ cotransport. Am. J. Physiol. 269:C1167-C1175.

36. Armsby, C.C., C. Brugnara, and S.L. Alper. 1995. Cation transport in mouse erythrocytes: role of $\mathrm{KCl}$ cotransport in regulatory volume decrease. Am. J. Physiol. C849-C902.

37. Krarup, T., and P.B. Dunham. 1996. Reconstitution of calyculin-inhibited $\mathrm{K}-\mathrm{Cl}$ cotransport in dog erythrocyte ghosts by exogenous PP-1. Am. J. Physiol. 270:C898-C902.

38. Lauf, P.K. 1983. Thiol-dependent passive $\mathrm{K} / \mathrm{Cl}$ transport in sheep red cells. I. Dependence on chloride and external $\mathrm{K}+[\mathrm{Rb}+]$ ions. J. Membr. Biol. 73:237-246.

39. Sattil, S.J., M.H. Ginsberg, and J.S. Brugge. 1994. Adhesive signaling in platelets. Curr. Op. Cell Biol. 6:695-704.

40. Lauf, P.K., and G. Valet. 1983. $\mathrm{Na}^{+} \mathrm{K}^{+}$pump and passive $\mathrm{K}^{+}$transport in large and small red cells populations of anemic high and low $\mathrm{K}^{+}$sheep. J. Cell Physiol. 116:35-44.

41. Nakano, H., E. Kobayashi, I. Takahashi, T. Tamaoki, Y. Kuzuu, and H. Iba. 1987. Staurosporine inhibits tyrosine-specific protein kinase activity of rous 
sarcoma virus transforming protein p60. J. Antibiot. (Tokyo). 40:706-708.

42. Yamaguchi, Y.F., and S. Kathuria. 1988. Characterization of receptor tyrosine-specific protein kinases by the use of inhibitors. Staurosporine is a 100times more potent inhibitor of insulin receptor than IGF-I receptor. Biochem. Biophys. Res. Commun. 157:955-962.

43. Secrist, J.P., I. Sehgal, G. Powis, and R.T. Abraham. 1990. Preferential inhibition of the platelet-derived growth factor receptor tyrosine kinase by staurosporine. J. Biol. Chem. 265:20394-20400.

44. Badwey, J.A., R.W. Erickson, and J.T. Curnutte. 1991. Staurosporine inhibits the soluble and membrane-bound protein tyrosine kinases of human neutrophils. Biochem. Biophys. Res. Commun. 178:423-429.

45. Johansen, J.W., and T.S. Ingebritsen. 1986. Phosphorylation and inactivation of protein phosphatase 1 by pp60 ${ }^{\mathrm{v}-\text { src }}$. Proc. Natl. Acad. Sci. USA. 83:207-211.

46. Ulug, E.T., A.J. Cartwright, and S. Courtneidge. 1992. Characterization of the interaction of polyomavirus middle $\mathrm{T}$ antigen with type $2 \mathrm{~A}$ protein phos- phatase. J. Virol. 66:1458-1467.

47. Chen, J., B.L. Martin, and D.L. Brautigan. 1992. Regulation of protein serine-threonine phosphatase type-2A by tyrosine phosphorylation. Science (Wash. DC). 257:1261-1264

48. Chen, J., S. Parsons, and D.L. Brautigan. 1994. Tyrosine phosphorylation of protein phosphatase $2 \mathrm{~A}$ in response to growth stimulation and $\mathrm{v}$-src transformation of fibroblasts. J. Biol. Chem. 269:7957-7962.

49. Joiner, C.A., R.S. Franco, M. Jiang, M.S. Franco, J.E. Barker, and S.E. Lux. 1995. Increased cation permeability in mutant mouse red blood cells with defective membrane skeletons. Blood. 86:4307-4314.

50. Tripodi, G., F. Valtorta, L. Torielli, E. Chieregatti, S. Salardi, L. Trusolino, A. Menegon, P. Ferrari, P.C. Marchisio, and G. Bianchi. 1996. Hypertension-associated point mutations in the adducin $\alpha$ and $\beta$ subunits affect actin cytoskeleton and ion transport. J. Clin. Invest. 97:2815-2822. 